\title{
The Power of Border Politics: On Migration in and outside Europe $^{1}$
}

\author{
Regina Kreide
}

Migration and the movements of refugees are embedded in a broader societal context in which our world is depicted as unstable, insecure and haunted by threats. Terrorist attacks, we learn, can occur almost everywhere and strike almost anybody; democracy is under pressure, autocratic leaders impose arbitrary political decisions on citizens; wars nearby and at its periphery shake Europe; the European welfare states face multiple challenges; and, in the middle of this, migration is presented as a danger to public order, cultural identity, and national labor-market policy. Open borders, and immigrants "pouring into Europe," be they refugees, asylumseekers or immigrants, are depicted as a major security problem. The threat becomes incarnated in the refugee and immigrant.

The question that comes up is whether there exists a right to exclude, a right to close borders - also for states that claim to be legitimate, in the sense that they respect human rights and are democratically organized. ${ }^{2}$ And what is the role of borders in publicly defining threats and forms of insecurity? Borders, I argue, are a multifaceted infrastructure that not only infringes on people's free movement. Moreover, borders are an instrument but also a condition for the creation of modes of securitization. As long as borders are imposed coercively, and through this, contribute to securitization, they are illegitimate. The reason for this, I show, is mainly because the power of securitizing restricts people's qualified options, structurally, by literally blocking their way out of war zones, hunger, and economic de-

1 I am grateful to criticisms and observations by many collegues involved in the SFB „Dynamics of Securitization“, especially Huub van Baar, Ana Ivasiuc, and Andreas Langenohl. Special words of thanks are due to collegues of the University of Washington Seattle, among them Amos Nascimiento, Bill Talbott, and Michael Forman. I also owe helpful insights and suggestion to Andreas Niederberger and collegues who participated in a conference at the University of Duisburg-Essen in November 2016.

2 Wellman/Cole 2011, pp. 2. 
privation, and, interactionally, by making migrants invisible, or depicting them as criminals, or victims. Sometimes, however, the security discourse itself reproduces certain stereotypes and neglects the migrant's power to de-securitize.

First, I will define what I mean by borders in this paper (1), then I will discuss some arguments to show that there are no good moral reasons in favor of closing borders (2), before taking you with me on a brief journey through the empirical world of the outer European border politics, and European law (3), and the border politics within Europe that effect migrants and also Roma minorities. Through this, I hope to offer a revealing argument against a "right" of states to exclude. Understanding state sovereignty as having the power to exclude allows for a transformation of our societies into securitized societies. This goes hand in hand with a notion of power that is directed to create securitization - with all kinds of problematical aspects for politics and our daily lives (4). Moreover, I show that these modes of securitization reveal that borders are not just walls but an accumulation of coercive practices that, nevertheless, are not all-encompassing but leave room for the power to de-securitize - however marginal it might be (5).

\section{Borders}

Borders building booming, even after the fall of the so-called Iron Curtain. Forty walls have been built worldwide since 1989. In Europe alone, the following walls are intended to prevent migration: the Spanish Exclave Ceuto and Melilla in North Africa; in northern Greece at the border with Turkey there is a wall 12,5 kilometers in length; at the ports of entry to Russia and the Republic of Belarus (this happened through the Baltic states); in the South east of Bulgaria at the border with Turkey (3 meters high and with a length of 35 kilometers, and 135 further kilometers are planned); Hungary has built a "provisionally" security installation at its border with Serbia which will be 175 kilometers, and with Croatia as well. Slovenia built a fence at the border with Croatia and Austria, and Macedonia set up a fence on the border with Greece. Border crossings are dangerous and cost lives. In 2015, at least 1,015,078 people crossed the Mediterranean to Europe; 3,771 had died in their attempts in 2015, even more in 2016, which was the deadliest year so far with at least 5,000 dead. Between Libya and Italy, the likelihood of dying is as high as one death for 
every 47 arrivals. Since the year 2000, more than 23,000 people have died on their way to the European continent. ${ }^{3}$

Borders are not just visible walls that hinder entry to a country and a nation-state's means to enact enforcement over its own territory. They do not just define physical entry to a country. They also appear, second, as a form of creating membership distinctions in a political and social community. Third, there are different kinds of social and cultural boundaries that deny people entry or full access to social and cultural participation in public life, as their way of life is not taken into account and they are confronted with various types of discrimination. All three forms are interconnected, an aspect that is often neglected in the philosophy debate but which becomes prevalent when focusing on security measures taken to install different shapes of borders. There is the case of territorial inclusion, but, nevertheless, either political exclusion or cultural disrespect, or even both (with regard to migrants and, for example, to the framing of immigration as a threat). There might be political inclusion (in the form of the possession of formal citizenship rights) but, nevertheless, territorial eviction and cultural discrimination also occur (as with European Roma, for example). In addition, there might be the rare case of overall cultural acceptance but territorial and political exclusion (as with Russian Germans or citizens of the former GDR - even though it is also a bit risky to say that there is no discrimination of "people from the East"). Borders are complex social institutions, characterized by practices of border crossing and enforcement mechanisms of all kinds. ${ }^{4}$ The question here is whether states are entitled to claim this triple remuneration, that is, legal, political, and cultural exclusion. ${ }^{5}$ Currently, there are some predominant arguments about why states are morally entitled to enforce their own immigration politics. Most of them are not convincing, as I will lay out in what follows.

\section{In favor of closed borders}

One argument is that states are comparable to marriages or private clubs that, to a certain degree, are in the privileged position to decide about their own affairs and matters. Just like a single person has a right to decide to

3 Luft 2016, p. 47.

4 Mezzadro/Neilson 2013, p. 3.

5 Cassee/Goppel 2012, p. 9. 
whom - if anyone - he or she will marry, a group of co-nationals has the right to decide whom - if anyone - it wants to invite to join the political community. ${ }^{6}$ This neglects, however, that there are major differences between the two aspects, the state and private association. States are not voluntary associations; we are usually born into a state and gain citizenship. One can terminate one's club membership even if there is no other club that will take him/her, but one cannot terminate one's citizenship so easily if no other states offers him/her its citizenship. Moreover, private associations are allowed to reject or "blackball" members, Kit Wellman argues, even if they are born in the clubhouse. A state, in contradistinction, is not allowed to reject the descendants of fully-fledged citizens, and de-naturalization violates international law. A basic idea here is self-determination, and it seems this embraces sovereignty over entry to the territory as well as over membership in a political community. Certainly, the members of the club, like the members of a state, do have good reasons to be interested in the admission requirements of their club or state. Moreover, new members are future decision-makers; it is part of collective selfdetermination to have control over who is and who will be the "self" that decides for itself. ${ }^{7}$

It seems that territorial exclusion and exclusion from the political community has been blurred. It is unclear why the presence of additional people on a territory would make a difference for the political community of members at all. It seems that the club analogy is meant to say that there is a right not to include citizens in the political, and thus in the citizenship community. Wellman argues that states are not allowed to deny admission to citizenship to immigrants who made it to the territory. This, he claims, is against the principle of 'relational equality,' which he considers to be important for any liberal state. ${ }^{8}$ Since states do have a right to exclude, the only option left for him is to link freedom of association with a territory principle. Wellman cannot clarify how the moral principle he sees at work when it comes to territorial restriction should be transferred to the realm of political exclusion. What one actually needs is a theory of territory. However, I think it would also be misleading, mainly because I cannot think of any reason why the mere entering of a territory, in the sense of a Kantian "visitation right," should be blocked at all.

6 Wellman 2008.

7 Cassee 2016, p. 43; Wellman 2008, p. 114.

8 Wellmann 2011, p. 75. 
This leads me to yet another objection in favor of a right to exclusion. One needs to bear in mind, according to David Miller, that freedom of movement is restricted even domestically. One is not allowed to go everywhere, to enter private property, and public institutions have opening hours and hours when you cannot visit. Miller concludes that it is sufficient for people to have at their disposal an adequate number of options relating to their "generic human interests" so that they can make meaningful decisions for their lives, with regard to their profession, religion, cultural activities and so on. ${ }^{9}$ But this assumption is problematic as well. A major issue I see is that freedom of movement is a very substantial freedom. Restricting this freedom majorly infringes on individual autonomy, as freedom of movement is a pre-condition of many other freedoms based upon the physical presence. This includes the freedom of career choice, love relationships, and housing conditions. It also restricts a substantial notion of self-determination. To move to places where the economic options seem to be better is a biblical theme; probably, it is as old as mankind. Moving is an important strategy in order to decide over oneself and in that sense an important right. As we, with a European passport, in most cases, are able to travel to most of the countries in the world without any visa restrictions, should know.

There is another important argument against international freedom of movement. It is again David Miller who argues that there exists a link between cultural homogeneity and social trust. People need to have trust in their political and welfare institutions which are organized according to principles of justice, and also cultural identity is an important source of this trust. ${ }^{10}$ The problem with this view is that it cannot explain why people affirm their support of social institutions based upon cultural and national homogeneity. Social services and just institutions are a value in itself. As long as people in need profit and the institutions work, support exists and is seen as legitimate. There would need to be a justification of trust that is independent from people's actual behavior (that is, refrain from support). This justification, and Miller see the problem as well, is a precondition of the trust argument. The instrumental value of nationality (serving as motivation for trust) depends itself on an intrinsic value: conationals must be convinced that their association (the state) is valuable

9 Miller 2016, p. 51.

10 Miller 2016, p. 64. 
and worth sustaining over time. ${ }^{11}$ Obviously, the argumentation is circular. It is assumed that people need to believe in cultural homogeneity and, if so, then they can be convinced to the support of social institutions.

Another objection is that taking self-determination seriously means rethinking what democratic self-determination means. The current immigration regulation has been made by a demos that includes only those who are domestically members of a state. If one takes the principle of democracy seriously, meaning that any coercive submission under rules requires that one should be the author of these rules, things look different. ${ }^{12}$ Then one needs to include all those who are coercively prevented from being a member, and this also includes immigrants who would like to enter the political community in question. To include everybody in creating and establishing the conditions for democratic norms aims at preventing a top-down variation of democracy. A strong notion of democracy, in contradistinction, includes everybody effected by enforceable rules. Seyla Benhabib's principle of juris generativity may help here. ${ }^{13}$ This refers to the "law's capacity to create a universe of normative meaning that can escape the providence of formal law making." The Universal Declarations of Human Rights (UDHR) and other international covenants and treaties have enabled actors such as women, linguistic, ethnic, political, sexual and religious minorities to enter the public sphere, and this praxis of inclusion has to be expanded beyond borders. It is exactly this idea of juris generativity that needs also be applied to refugees and immigrants.

But one could object now that not allowing people entry to a state or a political community is not coercive, and so any expansion of the democratic demos is not required. The situation, one could argue, is comparable with an individual who again and again wants to enter his neighbor's house because, for example, s/he does not like his/hers, or his/hers has no warm water, or no water at all. ${ }^{14} \mathrm{I}$ have a right to protect my property, but I might have a moral obligation to help him/her with, for example, warm water, but I am not obliged to let him/her in, just as little as I impose force on her by not letting him/her in. Is this convincing? I do not think so, because the example is misleading. It neglects the context of the problem and with it more complex questions, such as: Why is there no water? Who

11 Miller 2016.

12 Brunkhorst 2014; Abizadeh 2008.

13 Benhabib 2011.

14 Cassee 2016, p. 54. 
is responsible for this? How could one deal with the problem of water supply in a way all parties are satisfied? Who has defined the rules for defining the territory? When focusing on these questions, the topic becomes multifaceted; in fact, it may be that the neighbor has no water not because $\mathrm{s} /$ he has not paid his/her bill but because water supply in this part of the city has been of subordinated importance, and the infrastructure is not well developed. Those circumstances were imposed on him/her and are coercive insofar as the infrastructure measurements do not leave him/her qualified options to live a good life. The same holds for the migration situation. Seen from this angle, the problem can only be solved when the causes are thematized and the existing circumstances questioned. Neither neighbor is responsible for the situation, but an acceptable solution for all parties must be found. It is only then that coercive rules become legitimate. For this, all those affected in their generic interests, to use Miller's own term, should be included in the process of debating the effects of enforceable rules and in the decision-making process. This would require taking into account the interests of those waiting in camps at the outskirts of the European borders. However, borders "do" more than hinder people - if at all - to cross national or regional boundaries, enter new territory and political communities. They are more than an instrument used to enforce rules on people. They are coercive in themselves. This has to do with how the border is organized and exercised. Borders, I would like to show, incorporate the power to securitize, not just by being a wall but through social practices of securitization. To make this argument more convincing, I will now take you on a more empirical journey through European Union (EU) documents, immigration law, and security studies, and an analysis of the relationship between European borders and the creation of threat.

\section{Securitization of migration to Europe}

Open borders, refugees, immigrants, it is said, make our societies less secure; or rather, make our societies insecure. Terror attacks by alleged asylum-seekers seem to underpin this view. We all know that security issues do not necessarily reflect the objective, material circumstances of the world. Often, security issues are the result of the efforts of the elite, media, science, and politics to understand and shape the world. During the last 20 years or so, a series of studies has tried to understand why and how security is created, and what effects these different policy measures have on 
people's lives. I can only give a very rough overview here and will discuss three approaches before offering a dialectical understanding of securitization in order to understand the European border politics.

\section{Securitization}

Still influential is the so-called Copenhagen School, with scholars such as Ole Wæver and Barry Buzan. They criticized realist and neo-realist theories of international relations and claimed that security was a power balance among nation-states with rational and utilitarian agency on the side of states and their elites. "Security," according to them, is not a given prerogative of states, but is created through speech acts by political elites and other actors for the legitimation of political agency and supremacy. Speech acts perform "securitizing" with words, invoke a semantic repertoire, the so-called "grammar of security" 15 through which a social affair can be addressed as a "problem" (such as terrorism or migration), and this then allows for exceptional measures through a centralized authority (usually the government). Securitization, here, means calling something a security problem, and through this, triggering political measures to deal with it.

This approach has been - rightly, I think - criticized as being too preoccupied with the mere linguistic approach and the idea that a pragmatic turn in security studies would cover most phenomena regarding security. The so-called Paris School, represented by, for example, Didier Bigo and Thierry Balzacq, doubts this. They think the speech-act approach to security is too narrow, as it neglects the practices of securitization in a broader sense. What is meant here are practices that go beyond publicly-uttered speech acts, that is, ones which include weapons, walls, satellite techniques, and a whole range of administrative practices such as population profiling, risk assessment, a specific habitus of the security professionals, ${ }^{16}$ and, at EU level, data exchange and the activities of Frontex. Moreover, this approach does not just concentrate on states as securitizing actors but also includes non-state actors, such as companies, professionals, experts, and individuals. It also addresses the audience of security measures. Talking about something being a threat requires a public responsive to these ideas and images. By asking who actually accept the discourses on security, this approach focuses on the relationship between security

15 Buzan et al. 1998.

16 Bigo 2006. 
measures, the agents who bring up security threats, and an audience that is or is not responsive to this discourse. ${ }^{17}$ Securitization, put this way, means discursive and non-discursive ways of creating knowledge about security techniques that change the conduct of social, political, economic and military affairs.

Plausible as this "Paris School approach" might be, it still misses two aspects. First, it falls short of an analysis of how discursive and non-discursive practices are embedded in professional, including juridical, and technical contexts of power. The questions here are: Who has the power to define situations as being threatening? What are the effects of those policies? What are societal repertoires to respond? Andreas Langenohl distinguishes between the power to securitize and the power of securitization ${ }^{18}$ - a very helpful distinction for our scrutiny. The first distinction, the power to securitize, covers power as the power to address and frame a situation as pertaining to security. Regarding the migration issue, the more specific questions include: Who has the power to define what is a threat? How are refugees and migrants framed as being threats to the public order? The second aspect, the power of securitization, focuses on the intended and unintended effects that securitization measures have on people's lives. To find out about the power of securitization requires an analysis on how borders and border instruments infiltrate people's lives, the lives of refugees and immigrants but also those of the rest of the population. A third aspect of power is also very important here, namely, the power of desecuritization and, mirroring Langenohl's distinction, the power to desecuritize. Desecuritization - and this does not come as a surprise - is linked to securitization, a link which must be defined. As a first approximation, the following explanation may be sufficient. Whereas the power of desecuritization does not stem from an objective strategy to reveal securitizing measures but rather creative political counter-narratives to securitizing politics on an everyday basis, the latter, the power of desecuritization, focuses on political effects of counter-narratives and resistance politics. The power of and to desecuritization play important roles in defining what borders are and how to understand their coercive character, as we will see later.

17 Balzacq 2005, 2011; Bigo 2006; Leander 2010.

18 Langenohl, this volume. 
First, let me briefly return to the second blind spot of the Paris School that is, how exactly security and insecurity, as a result of a securitization policy, are linked. A plausible way of understanding securitizing measures is the following: security is not an objective condition but is constructed. It is constructed through intersubjective, shared interpretations within a social context and is directly linked to processes of securitization. So far, Paris School scholars would probably agree. However, those practices of security create insecurity, both are intrinsically linked. These practices come to the fore in a dialectical relationship in which the formation of security brings about its opposite, not a more secure world, but an insecure world. This happens, for example, through measures of "normalization," of political exclusion, surveillance and data collection. A dialectical- and Foucault-based approach includes not only a reflection on processes of discursive representation and construction, but also a critical interrogation of the techniques and forms of expertise that are involved in enacting, maintaining, reinforcing, or challenging migration-related processes of securitization. ${ }^{19}$

What does this entail for the migration and border issue? Refugees are not just unsure of whether they will survive their dangerous trips after they are forced to leave. Once they have made their journey with is privations and life-threatening routes to Europe, they again have to wait stressful months and sometimes years before getting legal acceptance as either an "asylum seeker" or as a "refugee", which then allows them to apply for fully-fledge citizenship after three years, or as so-called "beneficiary of protection" which makes them wait for seven years before being eligible to apply for a German passport. More than this, through European policy, refugees are framed as criminals, potential terrorists, and/or non-autonomous victims that need to be helped and, as an effect, are patronized. To offer a better picture, I take a closer look at how EU and German migration policy is deeply entrenched by securitizing power practices and how this can only be called coercive border control.

\section{The securitization of European borders}

In the mid-1980s, immigration became politicized through the issue of asylum. From the abolishment of border control between Schengen countries and the free movement of persons within the European Union, it fol-

19 Van Baar 2011a; van Baar 2013d. 
lowed that member states of the European Union (EU) lost decision-making authority over entry, residence, and exit. This was the begin of the "Fortress Europe". ${ }^{20}$ States lost steering authority as decisions of a single state in a space without internal frontiers naturally bears consequences for all member states. Nevertheless, the European Union and especially the member states did not want to give up on steering mechanisms for immigration of citizens from third countries. Two measures were taken: first, a more effective safeguarding of eternal borders; and, secondly, a Europeanization of asylum law.

\section{Safeguarding of external borders}

The European Union (EU) established a politics of "integrated border management," through which it endeavors to ensure that it can decide who enters and who is excluded, like a classical immigration country. Many actors are involved, such as EU institutions (European Commission, European Parliament, and the European Council), the Member States and Frontex, the EU border agency. Central aspects are increasing use of technology, outsourcing, privatization, and exterritorialization. Through this, the inclusion of third countries in the EU's border management became possible. This happened through repatriation agreements (with Morocco), and "neighbor politics" though which the legal immigration of citizens of this particular state are eased and, in turn, it is expected that a further wave of refugees is blocked (Turkey). The European Court of Justice (EUGH/ECJ/ CJEU) and the European Court of Human Rights (ECtHR) made it very clear that the norms of international refugee protection are also valid for EU institutions and agencies, including Frontex, when acting outside the European territory. This leads to the problem of how to deal with states that violate the human rights of refugees, which happens every day.

Amnesty International has already accused Turkey for months of forcing refugees to go back to their countries of origin, which include war-torn Afghanistan, Iraq and Syria. More and more people were caught on their way to Greece and were deported to EU-financed deportation camps in Erzurum, in the eastern part of Turkey. Without further legal assistance or an asylum procedure, they were deported from there to their countries of origin. This happened even though refugees from a country of war do have an international legal claim to a right to protection (non-refoulement).

20 Mrozek 2017, pp. 84-96. 
Turkey has pledged itself to respect the European and the Geneva Convention of Refugees. There is nothing quite like a "border" for blocking the way within existing law. Instead, blocking the way here entails having the option to either try to flee anew after having been deported back to the war-torn or insecure country of origin, or become an illegal person in Turkey. State leaders know that a mere sign on a wall would not prevent anybody. This is why the EU border control agency, Frontex, goes further than just controlling visible walls and fences. It has created border control that is backed by scientific knowledge and co-operation with hi-tech companies. $^{21}$

\section{Europeanization of asylum law}

In the 1980s, asylum was quickly connected to illegal immigration. In the Maastricht Treaty of 1992, asylum politics was integrated into the "third pillar" of co-operation, and this "third pillar," next to the first that handled economic, social and environmental policies, and the second that took care of foreign policy and military matters, brings together co-operation in the fight against crime. The Amsterdam Treaty of 1997 confirmed the "Hague Programme" of 2004, which was then further developed in the "Stockholm Programme" of 2014, in which asylum law was taken away from the sovereignty of the individual member state and was submitted to community law. A European-wide equal protection for asylum-seekers was to exist. Stockholm, indeed, led to a close-woven regulation system. However, the conditions under which to grant asylum, in terms of the social and healthcare performances, were not standardized. Standards for accommodation and support, for example, differ across and within member states, and this was taken as reason to allow for a huge amount of discretion. That

21 Frontex, we should note, is not a European border police agency, even though it has task that are police-like. It is rather a transnational administrative agency and is subordinated to national law. It has a budget that has increased from 19,2 million to 114 million euros between 2015 and 2016 (Luft 2016, p. 55).) Frontex is responsible for so-called "push back" operations, which are, according to the Geneva Refugee Convention, illegal and violate human dignity, according to ECtHR rulings since 2012. Nevertheless, they still exist, as previous Frontext Executive Director Ilkka Laitinen admitted recently. Frontex works, and we should keep this in mind, with full support of the European Internal Ministry, the European Commission and the majority of the European Parliament. Since Frontex has been criticized by the public, the member states tend to use Frontex as a scapegoat for human rights abuses rathen than the EU, which is the actual contracting authority. 
refugees and immigrants moved further to the North was expectable under those conditions.

The European-wide border control system utilizes advanced technology. Already in 1998 in an Austrian Presidency work program on Eurodac, a database of fingerprints from asylum applicants was commented on in the following: "The steep rise in the number of illegal immigrants and therefore potential asylum-seekers caught has revealed the increasing need to include their fingerprints in the system". ${ }^{22}$ Other regulations on migration in Europe followed. ${ }^{23}$ Eurosur has been brought into life to intensify information exchange between Schengen states and Frontex through data from satellite control in real-time. It functions in co-operation with the European Asylum Support Office (EASO), Europol (the EU's law enforcement agency), the EU Satellite Centre and the European Maritime Safety Agency, and all are coordinated through Frontex. ${ }^{24}$

What we can see from this admittedly rough first analysis of existing border policies is first that it is not sufficient, when closely-looking at border policing practices to think of a border as just a wall. Border control has become an industry in which science, technology, and politics work closely together. These material and technical ways to create borders have led to securitization. This happens, as we have seen, through discursive (as with European legal and political regulations, and media coverage) and non-discursive ways (collecting fingerprints, data storage systems, and satellite control) of creating knowledge about security techniques, and measures of "normalization" (surveillance processes in arrival camps, enforced distribution of refugees within an arrival country), of surveillance, and of data collection. ${ }^{25}$

Second, the power to securitize borders lies with European institutions that have created a network of control, surveillance, and deterrence. They function according to political decisions on a European level, backed by the respective national government. Behind those decisions stand real persons who have discussed those measures and have signed the orders. But as we know from systems theory, administrational institutions communicate with one another across functionalistic systems through codes that allow access to other systemic domains, without the involvement of the sub-

22 Statewatch 1998, cited in Huysmans 2000, p. 755.

23 Kostakopoulou 2000.

24 Luft 2016, p. 58.

25 Van Baar 2011a; van Baar 2013d. 
ject at all. The power to securitize is the power of the European elite to establish structures that then function as securitizing practices and governmental control. The power of securitization, however, becomes visible first and foremost in a "grammar of security," as Buzan puts it, a grammar that forms the condition of a performative speech-act of securitization. ${ }^{26}$ On the basis of this, as we have seen, the migrant is coined as a criminal, the other, a threat, an ascription.

\section{Securitization within Europe}

Enforcing measures with regard to migration happens not only at the outskirt of Europe. Securitization takes place also within Europe. Borders appear not just as walls and technical borders but as social and economic boundaries. The practices and discourses of securitization have tainted minority politics to an extent that they blur the distinctions betweens immigration and asylum politics, on the one hand, and minority politics regarding an "indegenious" minority, on the other.

The Roma in Europe are particularly affected by different security measures. Shortly after the fall of Communism, institutional discrimination and violent attacks by "ordinary citizens" against the Roma occurred throughout Central and East Europe. Human rights organizations and the European Union started to deal with the "Romani case" and framed it as a "human emergency". ${ }^{27}$ The adequate protection of the Romani minorities became one of the Copenhagen criteria for EU membership, formulated in 1993. It was in these days that the Roma were defined as a European minority that needed human rights protection. From the perspective of EU citizenship, ${ }^{28}$ there are (at least) two types of Roma citizens: those with a European passport who moved from eastern to the western European countries (mainly to Italy, France, and Germany), and exercised their rights of free movement; and Romani refugees from the former Yu-

26 Buzan et al. 1998.

27 Van Baar 2011.

28 EU citizenship, as we are aware, is one among many regimes in Europe that confers rights, and refers mainly to the legal side of citizenship. EU citizenship is sometimes used as the broader conception that includes political, cultural, and social aspects of citizenship, as well as how citizenship regimes emerge and change (Engin Isin/Michael Saward 2013, pos. 209). 
goslavia, who had fled the civil war and have already lived in Germany and other European countries for almost 20 years.

It was in this context of having recognized the Roma as a European minority that the European Commission stated that the Roma have difficulties in defending their basic human and citizenship rights, because of "their nomadic way of life". ${ }^{29}$ One needs to know that, throughout history, and surely nowadays, no more than $3 \%$ of Romani people were and are voluntarily travelers. Nevertheless, citizenship policy had to be applied, regardless of the fact that these Romani people held European passports. Italy, for example, started with some of these policy measurements. Around 1990, many Italian regions had already adopted laws aimed at the "protection of nomadic cultures." According to these laws, Roma "culture" needs to be "protected" through the construction and surveillance of segregated camps, the so-called campi nomadi. It was paradoxically the Italian authorities who "nomadized" the Roma by evicting them and forcing them to circulate within Italy. This irregulation of the Roma social mobility was used to reinforce the widespread prejudice that Roma do not belong to Italy, even though most of the Italy's Roma are Italian or non-Italian EU citizens. ${ }^{30}$ What is striking here is that in this context, citizenship and human rights are not seen as being unconditional, but require certain societal pre-conditions such as "being settled" in which "being settled" means "in a camp." Rather, citizenship rights are an instrument for securitizing the Roma people, in the name of emancipating them. EU citizenship is called into question when European citizens are evicted regardless of their European passports.

Let us briefly have a look at the siuation in Germany. The situation of the Romanian Roma in Germany is more complicated, but nonetheless shows also an ambivalance of the existing rights claims and the de facto exclusion of rights in the securitization discourses. Every summer, hundreds of Roma try to find informal work in the city of Berlin (and also Frankfurt and some of the other major cities). The newspapers reporting on this usually avoid mentioning that the people of this group of 'day laborers' are Romani. Mentioning this fact could lead either to swift discrimination and is historically seen as akin to the outright discrimination of a group that was previously persecuted under the Nazi regime. The pub-

29 European Commission 1999, p. 2, cited in van Baar 2011, p. 209; Atger 2013.

30 Van Baar 2011; Aradau et al. 2013; Ivasiuc, this volume. 
lic debate about the citizenship rights of Roma in Germany, however, switched from stressing Roma's right of free movement as European citizens, on the one side, and the view that they were unwanted foreigners who 'abuse' their right to the hospitality that German society offers to people in real danger, on the other. And, yet again, they were depicted as a threat to public order. ${ }^{31}$ At some point, some of the Romanian Roma in Berlin were provided with tourist status in an emergency situation. They were sheltered in a house for asylum-seekers, which is not a place for tourists, and were given some financial support so that they could return home (to Romania) after the legal established 90 days that a European citizen without financial means is allowed to stay. This situation shed a glaring light on German and European citizenship rights. The Roma demanded asylum in Germany. They fulfilled most of the criteria, such as being subject of permanent and systematic discrimination in their country of origin, being persecuted, evicted and pushed into a status of homelessness, and, as a consequence of this, being traumatized (Caglar/Mehling 2013). They wished to claim asylum in Germany, even though holding a European passport exceeds the border between European and non-European citizen. Being European citizens, Roma minorities from Romania are not eligible to enjoy the rights that refugees from "third countries" can. But, at the same time, they could not take advantage of the benefits of European citizenship, either.

German, as well as EU, citizenship fell short of guaranteeing this minority group their rights, even though they exercised their citizenship through their mere presence in different places. The Romanian Roma in Berlin enacted it, after having been deported back to Romania, by coming back to Germany a few weeks later, exercising their right to free movement. ${ }^{32}$ The way in which the Roma people articulated claims to asylum highlighted the limits of EU citizenship as well as human rights. They were denied basic rights in Germany despite the fact that they held European passports. The migration of this group, even if they hold European passports, is identified as an internal danger; with regard to the immigration of the Roma from Kosovo, which we do not have space to discuss here, is seen as an external danger. Securitization, such as being exposed to the techniques of control, normalization and exclusion, is a way of pro- 
ducing forms of non-belonging, and both citizenship and human rights are part of these exclusion processes.

In each example, I have illustrated the operation of the securitization discourse in forming and forging external and internal boundaries that exclude "the other" from citizenship and from being a full-fledge member of a political community. The discussion of the cases so far enables us to differentiate three aspects of securitization. Firstly, in the case of access both to residence and to citizenship, securitization shaped the outcomes in determining the conditions of access. Secondly, the securitization discourse contributes to marginalize, both symbolically and socio-economically, and becomes the framework and prism for claims of equal citizenship rights. Finally, the case of the Roma in Germany reveals the link between securitization and the denial of the exercise of citizenship rights even under the condition of being a member of the European Union. All these examples are at the end of a series of at least three aspects of a dialectics of securitization.

First, the Italian and German situations clearly illustrate how measures to "create security" and "stability" lead to a problematization of the Roma - in the form of nomadism, illegality, and public and private security threats. The supposed security measures establish insecurity for the Roma. And this constrains substantial options for members of this minority (as least when part of the groups effected), options that in Millers' terms touch generic interests such as housing, equal access to education, possibilities to find an adequate job that allows a living, and so on. Second, European regulations on minorities and migration are not designed to support inclusion and integration, nor to ground normative "correction" for the nationally framed citizenship law. Rather, it mirrors and reinforces the external foreclosure, the re-nationalization, and the internal border crossing within Europe and even within a European countries such as Germany, France, and Italy, to mention just three countries here that discriminate against Roma and migrants. There are different classes of European citizenship. There is citizenship for those who 'belong,' at least for the time being, and for those who should be expelled upon basis of their citizenship, as we have seen with the Roma. Citizenship can bring about exclusion, instead of more inclusion, and effect even those who do have a European passport. Third, not just the outer borders of Europe but also boundaries within Europe are coercive. Before we have seen that the safe-guarding of eternal borders leads to legal exclusion that may leave migrants some other options (going back to war or poverty) but those are options 
that do not qualify for a decent life (or generic interests). Seen from within Europe, legal inclusion of European citizens is also not necessarily followed by a political, nor a cultural inclusion (that is not highly discriminating). Romani people are not just prevented from social participation. Rather, social living conditions are imposed on them (such as living in camps, being harassed by vigilantes, and degrading representation in the media). The legally assured freedom of movement can easily be reversed, into the freedom to be moved and enforced border crossing and eviction. Roma people seem to be illegible to enjoy human rights since they are allegedly "nomadic" and therefore pose a security risk. These modes of securitizing people, of excluding them and neglecting their rights, are part of the pattern of denying social participating.

\section{The power to (de-)securitize}

The analyses of European border politics externally and internally have revealed at least two aspects that are closely related with what I have called the dialiectics of securitization. The following section first deals with the ambivalence of human rights, and the second with the power to securitize and the power of securitization.

\section{The ambivalence of human rights}

First, citizenship and human rights in the context of migration, we have seen, work as a securitizing frameowrk, identifying migrants and also $R o$ $m a$ as a special group of people, who do not belong to the community of human rights bearers, who need to be first made eligible to exercise human rights. Securitization, such as being exposed to techniques of control, normalization and exclusion, is a way of producing forms of non-belonging, and human rights are part of these exclusion processes. This highlights a more general problem with human rights. We could also see that human rights play an ambivalent role when it comes to securitization processes. They are conditions of freedom and resistance as well as instruments of oppression at the same time. How can this be the case? To better understand this dual character of human rights, we briefly need to recall the predominant notion of human rights. According to the liberal tradition, human beings are originally seen as a historical continuity with traditional natural law. They are a reaction to state absolutism and moralizing revolutions. The important characteristic features of the precursors of present- 
day human rights in natural law, shaped by John Locke, along with Charles de Montesquieu, are still important for the understanding of liberal human rights nowadays. They claim to be universally valid, they hold for every person, and they ask for a political order that protects individual freedom. In this reading, human rights mean that the individual has a right to exercise life, liberty, and property in security. ${ }^{33}$ Rights are an institutional guarantee of the private enjoyment of different goods and services. $^{34}$

Of course, the list of objections against this notion of human rights is very long, and I cannot go into this here in any length. ${ }^{35}$ Yet, there is a major pitfall of human rights that probably Karl Marx mentioned as one of the first. That is, freedom does not mean that one has the externally secured option to act as one likes according to one's will. Rather, freedom means the possibility of social participation. As long as freedom is understood as the undisturbed private realization of one's own will, the real social pre-conditions remain unseen. The normative individualism of the liberal human rights that are directed towards protecting individual security, be it the security of personal or economic freedom, is in tension with the idea of being "part of a society," or being a respected member of it. Human beings, Marx says, do not want, first and foremost, to obtain a fair share of societal resources. Rather, they want to be part of a community, to be people among others, being able to determine their social affairs politically. Human beings, it is supposed here, are political animals. Human rights in its liberal interpretation do not allow for this, when they claim individual security. They deny, paradoxically, some groups inside and outside territorial borders of Europe, migrants and Romani people, to be part

\section{Locke 1689.}

34 See also Menke 2016, p. 52.

35 It is misleading, a first objection says, or at least inaccurate, to say that one has human rights by nature in virtue of one's humanity, as "human nature" can be many things. Second, it is questionable whether one can, in fact, speak of continuity between the natural law approach and the present-day understanding of human rights, because the use of the concept "human rights" is relatively recent and found its way into general usage only after the foundation of the United Nations in 1945. A third difficulty is that the natural law approach does not sufficiently distinguish between values and rights ( $\operatorname{Raz} 2010: 323$ ). Basic necessities of life, such as having food or being able to live in peace, are essential values or interests whose realization we would support in all cases, and do not do need any reference to human rights at all. I think all of these criticisms are correct. 
of a political community. Hannah Arendt's often cited phrase - "one needs to have a right to have rights" - means precisely that nobody should be denied a legitimate claim to be a member of society, to belong to one, and not just to have a right to claim something against a state or an official organization, without the more inclusive claim to become a full-fledge member of this community. To deny this claim is coercive as it blocks a qualified option for the migrants and migrating European citizens to which they usually have no or unbearable alternatives. In the case of the Roma people, to restrict their free movement within Europe is against European law anyway.

\section{De-securitization}

The second aspect to discuss is related to the notion of power. Let us recall David Miller's claim that what is coercive about borders are the means used to enforce the border exclusion, not the borders themselves. ${ }^{36}$ Those means are part of the legitimate state power to exercise its sovereignty. Obviously, the notion of power used here is a Weberian one: a chance to impose one's own will against the reluctance of others within a social relation. ${ }^{37}$ Since Weber considered the notion of power to be vague, he preferred the more precise notion of authority, which means that a certain group of people has to obey rules ordered by others against their will. In this sense, borders themselves do not force people to do things and do not leave other options. Rather, the argument goes, a border just takes away one option among many others. In contradistinction to these notions of power and coercion, I argue that a coercive borders occurs when a group of people narrow down the options of others to the one thing that they want him or her to do and through this action further block other options to lead a self-determined life. It is the exclusion through borders themselves - be they national borders and borders within a country or region that can be a coercive act. It is an act of securitization in which the power to securitize is exercised, with all the effects on migrants and Roma people laid out above. That is why the power to securitize and the power of securitization (the effects of this power) cannot be reduced to a one-sided Weberian notion of power. A Foucauldian conception of comprehensive systems of truth (Episteme) and power constellations (dispositives) is more

36 Miller 2016, pp. 73-74.

37 Weber 1980, p. 28. 
adequate here. ${ }^{38}$ Power appears in all historical periods and in overlapping scientific, economic, institutional practices which mirror specific forms of "subjectiviation." These practices of daily life power normalize, control, and submit individuals, but, through this, the self-image of the subjects is created, which remains something that has been imposed. Securitzing practices do exactly that: they impose policies, images, and techniques through which a certain identity gets ascribed and fixated.

With this Foucauldian notion of power, we can also see that these power constellations are never absolute and all-compassing. There are forms of power that individuals and groups are not just subjected to but also empowered by. Power can set off subjectivations. It was only the late Foucault who established that forms of counter-power and freedom played a role, but he never worked this out systematically. This idea of 'counter power' is of great importance here. What we can observe is that among migrants, Roma, and ordinary citizens, modes of resistance against practices of securitization have occurred immediately. Those practices of de-securitization came up in niches of power, where the subjectivation turns into a breaking out of the iron discourse. Refugees in Budapest, for example, demonstrated against the degrading conditions to which they were subjected: without water, shelter, food in a railway station. Refugees demonstrated in almost all big but also middle-sized German cities, for example, in Augsburg, where they barricaded themselves in the house of the local union, demanding better treatment and acceptance as residents ("No human is illegal") or in Norderstedt, where they claimed (in German) "refugees are threatened but not a threat." Roma people too find creative ways to counteract securitization policies. Roma from Romania, for example, applied for asylum in Germany, even though European citizens are not officially eligible to do this. However, they fulfilled most of the criteria, such as being subject of permanent and systematic discrimination in their country of origin, being persecuted, evicted and pushed into a status of homelessness. ${ }^{39}$ By claiming asylum in Germany despite holding a European passport, they exceeded the border between European and non-European citizen and made borders within Europe visible at the same time. For sure, politically seen these are forms of de-securitization that appear to be marginally confronted with wide-spread practices of border controls exter-

38 Foucault 2008.

39 Caglar/Mehling 2013. 
nally and internally of Europe. Nevertheless, the everydayness of these protests gives an idea of how counter-power can occur and rebut forms of securitization, if only on a small scale.

\section{Conclusion}

To sum up, the "right to exclude" we have seen is not sustainable. States are not comparable with private clubs, and since they aim - at the liberal state - to represent some universal values like equality, it is not a moralfree zone and can be criticized for being exclusive in the wrong way. Trust is not necessarily based on national identify, and political self-determination should include everybody affected, also those outside the territory. In addition, borders, outer and inner borders, visible and digital, inherently embrace a force that drastically restricts options and this makes them coercive as long as they have been determined asymmetrically, without having asked those who are forced to accept them. Modern borders establish practices of securitization, at the ourskirts and within Europe, that make a border not just a wall but a functioning net of technical, industrial, and administraive control and securitizing power. Those practises not only block the entry of immigrants (more or less successful), but also infiltrate our daily lives and change modes of governance of all the citizens of Europe.

Whereas Agamben described the refugee as a symptom for a malaise of the modern state system, the refugee as an expression of human beings reduced to their bare lives, the public discourses right now identify in the bare life a permanent threat to public order. The refugee is no longer the symbol of the excluded, included through their unfortunate position in the camps. Rather, s/he has become a symbol of the included "enemy" who is dangerous like a "ticking bomb" and needs to be radically excluded. Human rights do not necessarily protect this group of human beings, as there is no strong commitment to make refugees an accepted member of community. Instead, we have seen with migrants and Roma people that human rights can easily be turned against those who are most vulnerable. Further, the power to securitze as well the power of securitzation may be enfenced by counterprotests but de-securitization remains marginal, though not impossible. Securitization measures, however, and we should be very aware of this, do not only affect immigrants but all of us. Who is next in being coined as a threat is an open questions that might be answered quicker than we hoped for. 


\section{References}

Abizadeh, Arash (2008): Democratic theory and border coercion: No right to unilaterially control your own borders. Political Theory 36: 37-65.

Aradau, Claudia / Huysman, Jef / Macioto, P.G./Squire, Vicki (2013): Mobility interrogating free movement: Roma acts of European citizenship. In: Engin F. Isin / Michael Sarward (eds.): Enacting citizenship. Cambridge: Cambridge University Press, pp. 132-154.

Arendt, Hannah (1951/1968). The Origins of Totalitarianism. Orlando/Austin/New York: Harvest.

Balzacq, Thierry (2011): A theory of securitization: Origins, core assumptions, and variants. In: Thierry Balzacq (ed.): Securitization theory: How security problems emerge and dissolve. London: Routledge, pp. 1-30.

Balzacq, Thierry (2005): Three faces of securitization: Political agency, audience, and context. European Journal of International Relations 11(2): 171-201.

Benhabib, Seyla (2011): Dignity in Adversary: Human Rights in Troubled Times. Cambridge/Malden: Polity Press.

Bigo, Didier (2006): Internal and external aspects of security. European Security 15(4): 385-404.

Brubaker, Rogers (1990): Immigration, citizenship, and the nation-state in France and Germany: A comparative historical analysis. International Sociology 5(4): 379407.

Buzan, Barry / Wæver, Ole / de Wilde, Jaap (1998): Security: A New Framework for Analysis. Boulder, CO: Lynne Rienner.

Buckel, Sonja (2013): “Welcome to Europe”. Die Grenzen des europäischen Migrationsrechts. Juridische Auseinandersetzungen um das "Staatsprojekt Europa". Bielefeld: transcipt.

Brunkhorst, Hauke (2014): Kritik und kritische Theorie. Baden-Baden: Nomos.

Caglar, Ayse / Mehling, Sebastian (2013): Sites and the scales of the law: Third-country nationals and the EU Roma citizens. Cambridge, Cambridge University Press.

Cassee, Andreas (2016): Globale Bewegungsfreiheit. Ein philosophisches Plädoyer für offene Grenzen. Berlin: Suhrkamp.

Filzwieser, Christian/Sprung Andrea (2014): Dublin III-Verordnung. Das Europäische Asyzuständigkeitssystem. Wien/Graz. ÖGB.

Foucault, Michel (2008): Analytik der Macht. Frankfurt am Main: Suhrkamp.

Huysman, Jef. (2000): The European Union and the securitization of migration. Journal of Common Market Studies 38(5): 751-777.

Isin, Engin F. (2013): Claiming European citizenship. In: Engin F. Isin/Michael Sarward (eds.): Enacting European Citizenship. Cambridge: Cambridge University Press, pp. 19-46.

Isin, Engin F./Sarward, Michael (eds.) (2013): Enacting European Citizenship. Cambridge: Cambridge University Press. 
Luft, Stefan (2016): Die Flüchlingskrise. Ursache, Konflikte, Folgen. München: C.H.Beck.

Mezzadro, Sandro/Neilson, Brett (2013): Border as Method: Or, the Multiplication of Labor. Durham/London: Duke University Press.

Miller, David (2016): Strangers in Our Midst: The Political Philosophy of Immigration. Cambridge, Mass.: Harvard University Press.

Mrozek, Anna (2017): Joint border surveillance at the external borders of 'Fortress Europe'. Taking a step 'further' with the European Border and Coast Guard. In: Sabine Hess et al. (eds.): Der lange Sommer der Migration. Grenzregime III. Berlin/ Hamburg: Assotiation A, pp. 84-97.

Van Baar, Huub (2015): The perpetual mobile machine of forced mobility: Europe's Roma and the institutionalization of rootlessness. In: Yolande Jansen/Joost de Bloois/Robin Celikates (eds.): The Irregularization of Migration in Contemporary Europe: Deportation, Detention, Drowning. London / New York: Rowman \& Littlefield, pp. 71-86.

Van Baar, Huub (2011): The European Roma: Minority Representation, Memory and the Limits of Transnational Governmentality. Amsterdam: University of Amsterdam.

Van Baar, Huub (2011): Europe's Roma: Problematization, securitization, nomadization. Environment and Planning D: Society and Space 29: 203-212.

Weber, Max (1980): Wirtschaft und Gesellschaft. Tübingen: Mohr.

Wellman, Christopher Heath (2011): Immigration and freedom of association. Ethics 119(1): 109-141.

Wæver, Ole (1995): Securitization and desecuritization. In: Ronnie D. Lipschutz (ed.): On Security. New York: Columbia University Press, pp. 46-86. 